\title{
Chapter 12 \\ Evaluating Removal of Radionuclides from Landfill Leachate Using Generally Practiced Wastewater Treatment Processes
}

\author{
Nao Kamei-Ishikawa, Ayumi Ito, and Teruyuki Umita
}

\begin{abstract}
Some amounts of the radionuclides released in the nuclear accident at the Fukushima Daiichi Nuclear Power Plant are transferred to wastes such as sewage sludge ash and municipal waste ash. Among these wastes, those that contain less than $8,000 \mathrm{~Bq} / \mathrm{kg}$ radiocesium are being disposed in controlled landfill sites that have been in use since before the accident. At the landfill sites, a leachate treatment system is generally used, and there are no specific treatment steps for removal of radionuclides. In this study, the stable element concentrations of the relevant radionuclides in the leachate and treated water at each treatment step were determined to evaluate the radionuclide removal at each step. Target elements in this study were $\mathrm{Cs}, \mathrm{Co}, \mathrm{Mn}, \mathrm{Ni}$, and Sr. More than $93.9 \%$ of the $\mathrm{Co}, \mathrm{Mn}, \mathrm{Ni}$, and $\mathrm{Sr}$ present in the leachate could be removed at the alkali removal step by precipitation; however, $\mathrm{Cs}$ could not be removed by any of the treatment processes.
\end{abstract}

Keywords Cesium $\bullet$ Cobalt $\bullet$ Fractionation $\bullet$ Landfill leachate $\bullet$ Leachate treatment - Manganese $\bullet$ Nickel $\bullet$ Stable isotopes $\bullet$ Strontium

\subsection{Introduction}

Radionuclides such as ${ }^{134} \mathrm{Cs},{ }^{137} \mathrm{Cs},{ }^{90} \mathrm{Sr}$, and ${ }^{239+240} \mathrm{Pu}$, which were released to the environment in the nuclear accident at the Fukushima Daiichi Nuclear Power Plant, have been found in bottom ash and fly ash of incinerated wastes produced in

\footnotetext{
N. Kamei-Ishikawa $(\bowtie) \bullet$ T. Umita

Department of Civil and Environmental Engineering, Iwate University,

Ueda 4-3-5, Morioka, Iwate 020-8551, Japan

e-mail: naoki@iwate-u.ac.jp
}
A. Ito
Department of Frontier Materials and Function Engineering, Graduate School of Engineering, Iwate University, Ueda 4-3-5, Morioka, Iwate 020-8551, Japan 
Fukushima Prefecture, Japan [1]. ${ }^{134} \mathrm{Cs}$ and ${ }^{137} \mathrm{Cs}$ have been found in sewage sludge produced in a wide area of northern and eastern Japan [2]. The Japanese government divides wastes into three types, depending on radiocesium concentration in the waste, and each type has its own disposal methods [3]. For the waste with the lowest level of radiocesium concentrations $(<8,000 \mathrm{~Bq} / \mathrm{kg})$, controlled landfill sites can be used as the disposal place. The radiocesium concentrations in sewage sludge ash produced in Iwate Prefecture have been lower than $8,000 \mathrm{~Bq} / \mathrm{kg}$; therefore, these ashes have been disposed in a controlled landfill site that has been used since before the nuclear accident.

Controlled landfill sites have leachate treatment systems. Although leachate characteristics depend on the individual sites, generally leachate has high alkalinity and contains a high organic matter content and a large amount of suspended solids [4]. To remove these contaminants, several types of treatment steps are used: coagulation-flocculation, chemical precipitation, membrane filtration, activated carbon adsorption, biological treatment, and ion-exchange treatment [5]. However, the extent of removal of any radionuclides present in the leachate by existing treatment steps is not clear.

The objective of this study was to evaluate radionuclide removal from the leachate sampled at a controlled landfill site. Stable elements were analyzed as analogues of the radionuclides. The main elements studied were $\mathrm{Co}, \mathrm{Cs}, \mathrm{Mn}, \mathrm{Ni}$, and $\mathrm{Sr}$; their radionuclides $\left({ }^{58} \mathrm{Co},{ }^{60} \mathrm{Co},{ }^{134} \mathrm{Cs},{ }^{137} \mathrm{Cs},{ }^{54} \mathrm{Mn},{ }^{59} \mathrm{Ni}\right.$, and $\left.{ }^{63} \mathrm{Ni}\right)$ were actually detected or expected to be found in environmental samples collected after the nuclear accident [6].

\subsection{Materials and Methods}

\subsubsection{Sample Collection}

Samples were collected from the Iwate Clean Center landfill site in Iwate Prefecture, Japan. The site is separated into two blocks: block I (landfill capacity, $50,300 \mathrm{~m}^{3}$ ) and block II (landfill capacity, 75,000 $\mathrm{m}^{3}$ ). Block I is now closed, whereas more than half of the landfill capacity of block II remains available. Major wastes buried in the landfill site have been combustion residue $(26,000 \mathrm{t})$, glass, concrete, and ceramic $(25,000 \mathrm{t})$, and inorganic sludge $(10,000 \mathrm{t})$.

A flow sheet of the leachate treatment system that indicates sampling points is shown in Fig. 12.1. Leachates from blocks I and II are mixed in the regulating reservoir. Samples were taken after the following steps: regulating reservoir (raw leachate, RL); alkali removal step using sodium carbonate (AR); biological treatment step (BT); membrane filtration step (MF); activation carbon adsorption step (AC); and chelating and zeolite adsorption step (effluent water, EW). Samples were taken in July, September, and December 2012 at all locations, except for the AC, which was only sampled in September and December. Zeolite adsorption for radiocesium 


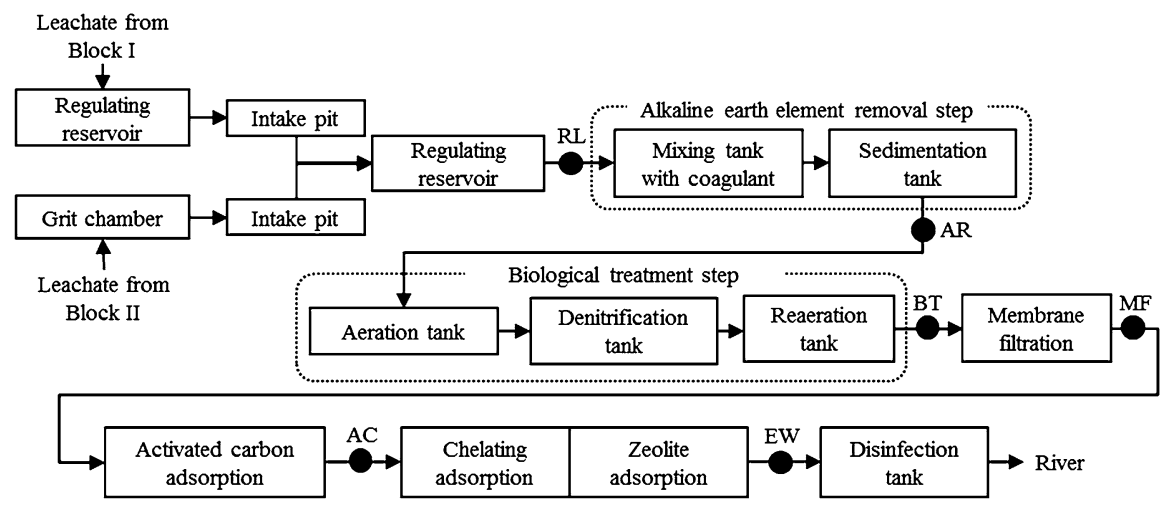

Fig. 12.1 Leachate treatment system with sampling points (filled circles)

adsorption was added to the process from May 2012. There is a $\mathrm{pH}$ regulating tank after each step.

The precipitate in the sedimentation tank at the AR step was collected in December to determine the distribution between liquid phase and solid phase (precipitates) for each element.

\subsubsection{Determination of Characteristics of Samples}

Chemical characteristics of the samples were determined. The $\mathrm{pH}$ was measured with a pH meter (HM-25R; TOADKK). Suspended solids (SS) were determined in duplicate by the standard method [7]. Total organic carbon content (TOC) was determined three times using a TOC analyzer (TOC-V; Shimadzu).

Concentration analyses of the target elements (Cs, $\mathrm{Sr}, \mathrm{Co}, \mathrm{Ni}$, and $\mathrm{Mn}$ ) and major elements were based on standard methods for examination of wastewater [7]. These analyses were done in triplicate. First, $100 \mathrm{~mL}$ of sample was digested with $1 \mathrm{~mL}$ concentrated $\mathrm{HNO}_{3}$ and $0.5 \mathrm{~mL}$ concentrated $\mathrm{HCl}$, and then evaporated on a hot plate at around $120{ }^{\circ} \mathrm{C}$. Next, deionized water was added to the sample to make a solution volume of $100 \mathrm{~mL}$. The sample solution was filtered through a $0.45-\mu \mathrm{m}$ membrane filter. Element concentrations in the filtrate were measured using an inductively coupled plasma (ICP) mass spectrometer (iCAP Qs; Thermo) and ICP atomic emission spectrometer (Shimadzu, ICPE-9000). Standard solutions were purchased from Merck Chemicals (CertiPUR series). No contaminations of the analyzed elements were found in a processed blank.

The precipitate collected in the sedimentation tank at the AR step was also analyzed to determine concentrations of each element in the solid phase in the precipitate as already described. 


\subsubsection{Determination of Physical and Chemical Forms of the Target Elements in Raw Leachate}

Filtration and ion-exchange methods were used to determine three fractions of each element in RL sample: particulate, cationic, and anionic fractions. The particulate fraction was the solid phase retained by filtration through a $0.45-\mu \mathrm{m}$ membrane filter. The filtrate was used for further fractionation.

Two types of ion-exchange resins, an anion-exchange resin (AER) (IRA402BL; Amberlite) and a cation-exchange resin (CER) (IR120B-Na; Amberlite), were used to determine the ion species of each element in the filtrate. A preliminary experiment confirmed that the cations of the target elements were retained by CER but not by AER.

After passing through the $0.45-\mu \mathrm{m}$ membrane filter, the filtrate was passed through the AER or CER resin column separately. Each column eluent was analyzed for the element concentrations using the ICP mass spectrometer. The cation form fraction or the anion form fraction was the fraction that passed through the AER or CER, respectively.

\subsection{Results and Discussion}

\subsubsection{Characteristics of the Samples}

Table 12.1 shows SS, TOC, and $\mathrm{pH}$ in each sample. SS in the RL sample had a wide variation. Sediments in one of the two intake pits were moved to another pit during the pit maintenance between July and September; therefore, the turbidity in the pit in September was the highest, causing a wide variation of SS. More than $84 \%$ of the SS in the RL was removed at the AR step, and then after the BT step, more than $93 \%$ of the SS in the RL was removed. On the other hand, TOC was lowered after the MF step.

Table 12.1 Suspended solids (SS), total organic carbon (TOC), and $\mathrm{pH}$ in samples

\begin{tabular}{|c|c|c|c|c|c|c|c|c|c|}
\hline & \multicolumn{3}{|c|}{$\mathrm{SS}(\mathrm{mg} / \mathrm{L})$} & \multicolumn{3}{|c|}{$\mathrm{TOC}(\mathrm{mg} / \mathrm{L})$} & \multicolumn{3}{|l|}{$\mathrm{pH}$} \\
\hline & Max & Min & Mean & Max & Min & Mean & $\operatorname{Max}$ & Min & Mean \\
\hline$\overline{R L}$ & 281 & 77 & 182 & 23 & 15 & 18 & 7.4 & 7.2 & 7.3 \\
\hline $\mathrm{AR}$ & 15 & 5.3 & 11 & 23 & 10 & 15 & 10.0 & 8.3 & 9.2 \\
\hline BT & 5.0 & 1.6 & 3.1 & 30 & 12 & 18 & 7.7 & 7.2 & 7.5 \\
\hline MF & 1.3 & $<0.4$ & 0.9 & 8.2 & 1.8 & 5.7 & 7.1 & 6.7 & 6.9 \\
\hline $\mathrm{AC}$ & 1.2 & $<0.1$ & 0.7 & 3.5 & 2.3 & 2.9 & 6.9 & 6.9 & 6.9 \\
\hline EW & 2.2 & $<0.4$ & 1.2 & 5.1 & 3.7 & 4.3 & 7.1 & 6.8 & 7.0 \\
\hline
\end{tabular}




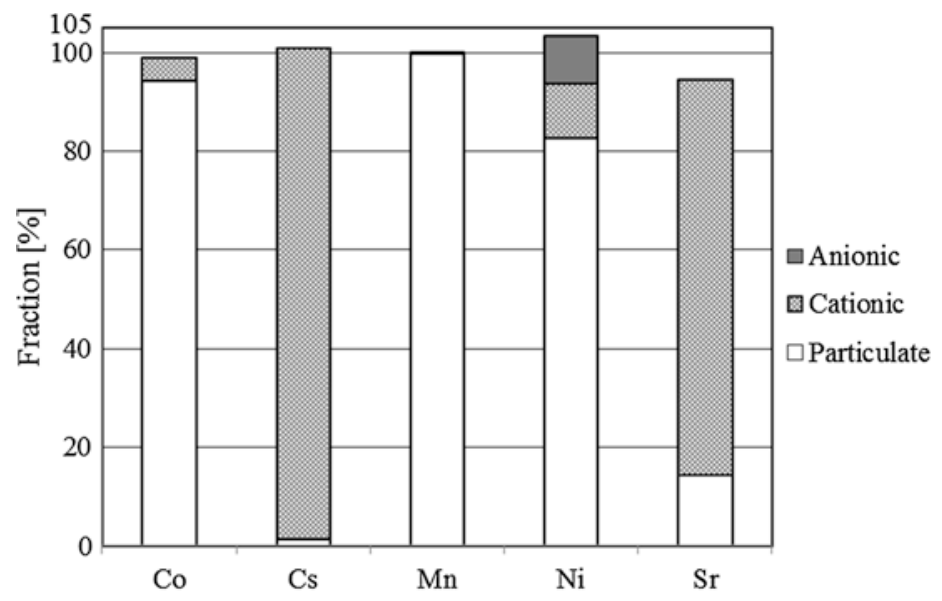

Fig. 12.2 Element fractionation in the raw leachate (RL) sample

\subsubsection{Element Fractionation in the Raw Leachate Sample}

For the RL sample collected in December, concentrations of $\mathrm{Co}, \mathrm{Cs}, \mathrm{Mn}, \mathrm{Ni}$, and $\mathrm{Sr}$ were $13.4,3.3,1,810,87.7$, and $3,960 \mu \mathrm{g} / \mathrm{L}$, respectively. The distribution of the element concentrations in each fraction were obtained as shown in Fig. 12.2. The filtration and ion exchange were carried out with good recovery ratios ranging from $94.6 \%$ to $103 \%$. More than $82 \%$ of the $\mathrm{Co}, \mathrm{Ni}$, and $\mathrm{Mn}$ was present in the particulate fraction. $\mathrm{Mn}$ exists as brown-colored $\mathrm{Mn}_{3} \mathrm{O}_{4}$ when it is incinerated at temperatures higher than $800{ }^{\circ} \mathrm{C}$ [8]. Because waste is generally incinerated above $800{ }^{\circ} \mathrm{C}$ and the color of the suspended solid was brown in the RL sample, Mn should be present as $\mathrm{Mn}_{3} \mathrm{O}_{4}$. Some $\mathrm{Ni}$ was in anionic form $(9.5 \%)$ and slightly more in cationic form $(11 \%)$. Ni is present as $\mathrm{Ni}^{2+}$ in the water environment [9], and it is also combined with organic matter $[10,11]$. Organic matter has several functional groups such as phenolic, carboxyl, and carbonyl [12]. The leachate filtrate contained $13.8 \mathrm{mg} / \mathrm{L}$ dissolved organic carbon. Therefore, a part of the $\mathrm{Ni}$ in the leachate could be combined with dissolved organic matter and then exist in anionic form.

Cationic forms were dominant for $\mathrm{Cs}$ and $\mathrm{Sr}$ (Fig. 12.2). Most of the Cs and $\mathrm{Sr}$ would be present as $\mathrm{Cs}^{+}$and $\mathrm{Sr}^{2+}$ under the $\mathrm{pH}$ and Eh conditions [9]. The principal form of $\mathrm{Cs}$ in municipal waste fly ash was suggested to be $\mathrm{CsCl}$, which has high solubility [11]; this was attributed to the fact that the extraction ratios of Cs from five municipal waste fly ash samples ranged from $64 \%$ to $89 \%$ [13]. In contrast, extraction ratios of $\mathrm{Cs}$ from the municipal solid waste incinerator bottom ash and sewage sludge ash were less than $5.6 \%$ and $2.7 \%$, respectively $[13,14]$. Therefore, Cs in the leachate was from municipal waste fly ash, and the insoluble forms of Cs could not move downward with the leachate. For Sr, insoluble fractions were around $25 \%$ in municipal waste fly ash and bottom ash and more than $40 \%$ in sewage sludge ash [13], which implied that $\mathrm{Sr}$ in the leachate could originate from different types of waste. 


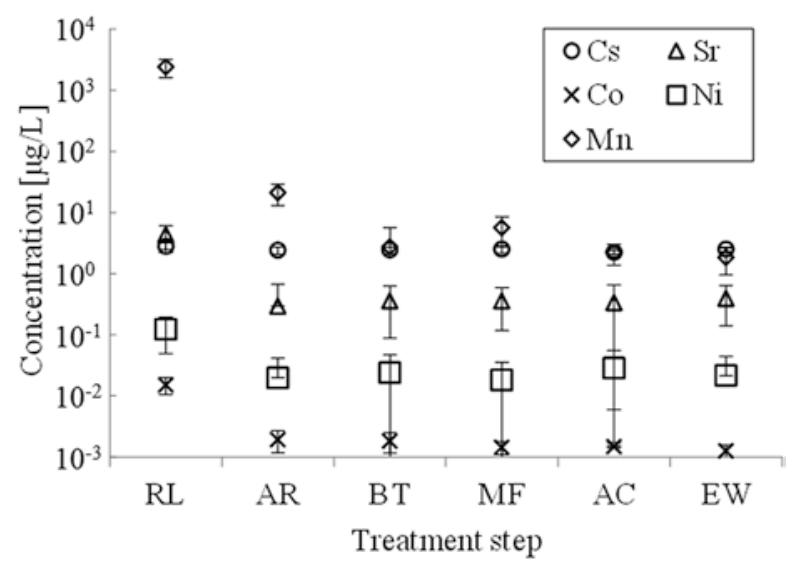

Fig. 12.3 Element concentrations in samples at each treatment step. Error bars show the standard deviation of three replicates

\subsubsection{Element Concentration in Samples at Each Treatment Step}

Figure 12.3 shows the element concentrations in samples at each treatment step. Co, $\mathrm{Mn}, \mathrm{Ni}$, and $\mathrm{Sr}$ concentrations in RL were lowered at the AR step. The removal rates at the AR step for $\mathrm{Co}, \mathrm{Mn}, \mathrm{Ni}$, and $\mathrm{Sr}$ were $87.3 \%, 99.1 \%, 83.9 \%$, and $93.2 \%$, respectively. However, Cs concentration was not changed at any treatment steps.

As already described, except for $\mathrm{Cs}$, all the target elements were removed from the RL at the alkali removal step. To obtain the degree of precipitation, the distribution coefficient $\left(K_{\mathrm{d}}\right)$ for each element was calculated by the following equation:

$$
K_{\mathrm{d}}=C_{\text {solid }} / C_{\text {liquid }}
$$

where $C_{\text {solid }}$ is an element concentration in the solid phase (precipitate) and $C_{\text {liquid }}$ is an element concentration in the liquid phase (AR sample). Table 12.2 shows the $K_{\mathrm{d}}$ values for the target and major elements of the precipitate at the AR step. At this step, $\mathrm{Na}_{2} \mathrm{CO}_{3}$ was added as a reagent for removing alkalinity. $\mathrm{Na}$ concentration was $1.5 \mathrm{~g} / \mathrm{L}$ in the $\mathrm{RL}$ and then rose to $2.2 \mathrm{~g} / \mathrm{L}$, which implied at least $1.5 \times 10^{-2} \mathrm{~mol} / \mathrm{L}$ $\mathrm{CO}_{3}{ }^{2-}$ ion was added at the AR step. $\mathrm{Ca}$ and $\mathrm{Sr}$ had high $K_{\mathrm{d}}$ values and were present mostly as cationic forms in the RL sample. The solubility products of $\mathrm{CaCO}_{3}$ and $\mathrm{SrCO}_{3}$ are quite low $\left(10^{-8.3}\right.$ for $\mathrm{Ca}$ and $10^{-10}$ for $\left.\mathrm{Sr}\right)$ [15]; therefore, these elements in the RL must be precipitated by the following reactions:

$$
\begin{aligned}
& \mathrm{Na}_{2} \mathrm{CO}_{3}+\mathrm{Ca}^{2+} \rightarrow \mathrm{CaCO}_{3} \downarrow+2 \mathrm{Na}^{+} \\
& \mathrm{Na}_{2} \mathrm{CO}_{3}+\mathrm{Sr}^{2+} \rightarrow \mathrm{SrCO}_{3} \downarrow+2 \mathrm{Na}^{+}
\end{aligned}
$$


Table 12.2 $K_{\mathrm{d}}$ values of the precipitate at the alkali removal (AR) step for each element

\begin{tabular}{ll}
\hline & $K_{\mathrm{d}}(\mathrm{L} / \mathrm{kg})$ \\
\hline $\mathrm{Co}$ & $1,456 \pm 111$ \\
$\mathrm{Cs}$ & $67 \pm 4$ \\
$\mathrm{Mn}$ & $20,549 \pm 3,304$ \\
$\mathrm{Ni}$ & $1,215 \pm 72$ \\
$\mathrm{Sr}$ & $1,530 \pm 101$ \\
$\mathrm{Ca}$ & $5,015 \pm 280$ \\
$\mathrm{~K}$ & $1.9 \pm 0.4$ \\
$\mathrm{Mg}$ & $90 \pm 14.8$ \\
$\mathrm{Rb}$ & $3.4 \pm 1.0$ \\
\hline
\end{tabular}

In addition, particulate fraction could be coprecipitated by the increasing $\mathrm{pH}$ at the AR step, which would explain why $\mathrm{Co}, \mathrm{Mn}$, and $\mathrm{Ni}$ also had high $K_{\mathrm{d}}$ values.

Although the zeolite adsorption step introduced for Cs adsorption was not effective for Cs removal, Takano et al. [16] succeeded in developing a radiocesium removal treatment system from a leachate in a general waste disposal landfill site, and in fact, the system has been introduced to a landfill site in Gunma Prefecture [16]. At the Iwate Clean Center landfill site, use of zeolite was begun in an adsorption tower in May 2012, and the zeolite had not been exchanged by the collection of the last samples in the present study (December 2012). Adsorption sites on the zeolite must be occupied by not only Cs but also other major cations such as $\mathrm{K}$ and $\mathrm{Ca}$. $\mathrm{K}$, especially, which is most like Cs with similar chemical properties, had a concentration in the AC that was $1.5 \times 10^{5}$ times higher than the Cs concentration. From this fact, little Cs could be adsorbed by the zeolite. Consequently, frequent changing of zeolite or introduction of another new type of treatment system may be necessary for effective Cs removal.

\subsection{Conclusions}

In this study, the possibility of radionuclide removal from landfill leachate was evaluated by using generally practiced leachate treatment processes. As a result, more than $93.9 \%$ of the $\mathrm{Co}, \mathrm{Mn}, \mathrm{Ni}$, and $\mathrm{Sr}$ present in the RL could be removed at the alkali removal step by coprecipitation or precipitation as carbonate. Cs could not be removed by any treatment steps, even though there was a zeolite adsorption step. Cs removal can be achieved by frequently exchanging the zeolite in the zeolite adsorption tank. However, because that will generate more wastes and increase costs, it is necessary to adopt another treatment step for Cs removal.

Acknowledgments This work was partly supported by JSPS KAKENHI Grant Number 12014030.

Open Access This article is distributed under the terms of the Creative Commons Attribution Noncommercial License which permits any noncommercial use, distribution, and reproduction in any medium, provided the original author(s) and source are credited. 


\section{References}

1. Ministry of the Environment (2012) Additional information of 13th Commission of safety assessment for disaster waste disposal. http://www.env.go.jp/jishin/index.html\#haikibutsu. Accessed 9 July 2013 (in Japanese)

2. Ministry of Land, Infrastructure, Transport and Tourism (2013) Measurements of radioactive concentrations in sewage sludge etc. http://www.mlit.go.jp/mizukokudo/sewerage/mizukokudo_ sewerage_tk_000211.html. Accessed 9 July 2013 (in Japanese)

3. Ministry of Land, Infrastructure, Transport and Tourism (2011) The approach to immediate handling of secondary byproducts of water and sewage treatment in which radioactive materials were detected. http://www.nsr.go.jp/archive/nisa/english/press/2011/09/en20110909-2-2.pdf. Accessed 9 July 2013

4. Rowe PK, Quigley RM, Brachman RWI et al (2004) Barrier systems for waste disposal facilities. E\&FN Spon, London

5. Kurniawan TA, Lo WH, Chen GYS (2006) Physico-chemical treatments for removal of recalcitrant contaminants from landfill leachate. J Hazard Mater 129:80-100

6. WHO (2012) Preliminary dose estimation from the nuclear accident after the 2011 Great East Japan Earthquake and Tsunami. WHO, Geneva

7. Japan Sewage Works Association (1997) Wastewater examination method, vol 2. Japan Sewage Works Association, Tokyo (in Japanese)

8. Greenwood NN, Earnshaw A (1997) Chemistry of the elements, 2nd edn. ButterworthHeinemann, Oxford

9. Pourbaix M(1974) Atlas of electrochemical equilibria in aqueous solutions. National Association of Corrosion Engineers, Houston

10. Mellis EV, Cruz MC, Casagrande JC (2004) Nickel adsorption by soils in relation to pH, organic matter and iron oxides. Sci Agric 61:190-195

11. NITE (2008) Risk assessment of chemical substances, vol 69. National Institute of Technology and Evaluation, Tokyo (in Japanese)

12. Kumada K (2001) Chemistry of soil organic matter. Japan Scientific Societies Press, Tokyo (in Japanese)

13. NIES (2012) Appropriate waste disposal in terms of radionuclides behavior, technical data. National Institute of Environmental Studies, Tsukuba (in Japanese)

14. Tsushima I, Ogoshi M, Yamashita $\mathrm{H}$ et al (2013) Behavior of radioactive cesium in wastewater treatment plants and dissolution test of contaminated sewage sludge. J Jpn Soc Water Environ 36:23-28 (in Japanese)

15. Charlot G, Sone K (1974) Chemical reactions in solution. Kyoritsu Shuppan, Tokyo (in Japanese)

16. Takano T, Tamura Y, Nishizaki Y et al (2012) Radiocesium removal from leachate in general waste disposal using zeolite. Tishiseisou 65:218-222 (in Japanese) 